\title{
Restraining Reconciliation for Retribution in the Treaty of Peace with Japan: An Empirical Research of Jus Post Bellum
}

\author{
Keisuke Minai ${ }^{1}$ \\ ${ }^{1}$ Graduate School of Law, Keio University, Tokyo, Japan \\ Correspondence: Keisuke Minai, Graduate School of Law, Keio University, Tokyo, Japan. E-mail: \\ k_mi_na_i@a6.keio.jp
}

Received: August 26, 2014 Accepted: September 7, 2014 Online Published: November 19, 2014

doi:10.5539/jpl.v7n4p148 URL: http://dx.doi.org/10.5539/jpl.v7n4p148

\begin{abstract}
This article addresses the question regarding post bellum norms of how to balance the antagonism between retribution and reconciliation. Therefore, the author conducts empirical and inductive research, considering the Treaty of Peace with Japan, specifically analyzing the process of drafting provisions for war criminals of this treaty. These analyses indicate that the methodology, which secures retribution through restrained reconciliation, is embodied in Article 11 of the Treaty of Peace with Japan. The findings of this study suggest that restraining reconciliation for retribution as well as relaxing retribution for reconciliation is acceptable for implementing post bellum norms.
\end{abstract}

Keywords: amnesty in peace treaties, jus post bellum, reconciliation, retribution, the Treaty of Peace with Japan, war criminals

\section{Introduction}

The question of how to balance the antagonism between retribution and reconciliation, or between punishment and amnesty, can be posed with respect to post bellum norms, ${ }^{1}$ which have evolved into a novel discipline in international legal studies. Stahn analyzes the context of contemporary international practice, which grants amnesty for less serious crimes, with "a combined justice and reconciliation model" positioned as one of the principles of post-conflict law. ${ }^{2}$ However, he has not explained the specific contents of this combined model. Identifying retribution, reconciliation, ${ }^{3}$ and proportionality as normative principles of jus post bellum, May

\footnotetext{
${ }^{1}$ International lawyers who focus on the norms referred to as jus post bellum raise the controversial point of whether the norms are legally binding. Österdahl stresses the possibility of jus post bellum having a realistic framework, by virtue of "custom-making" or "tailor-made" frameworks corresponding to individual situations after conflict, and he defines jus post bellum not as positive laws, but as criteria for evaluating other laws (Österdahl, I., \& Zadel, E. (2009). What Will Jus Post Bellum Mean? Of New Wine and Old Bottles. Journal of Conflict \& Security Law, 14(2), 175-207. pp. 191-192; Österdahl, I. (2012). Just War, Just Peace and the Jus post Bellum. Nordic Journal of International Law, 81, 271-294. p. 281). Boon remarks that "Jus post bellum contains many norms and objectives that are not settled law, but are, instead under construction" (Boon, K. (2012). Jus Post Bellum in the Age of Terrorism: Introductory Remarks. Am. Soc'y Int'l L. Proc., 106, 331-332. p. 331). Easterday defines soft law under jus post bellum, although this jus is considered to be based on existing laws (Easterday, J. (2012). Jus Post Bellum in the Age of Terrorism: Remarks by Jennifer Easterday. Am. Soc'y Int'l L. Proc., 106, 335-337. p. $335)$.

In this paper, the author adopts the terminology "post bellum norms" in the light of these treatments of binding authority; it is not designed to address the question of whether jus post bellum can be legally binding.

Note that the post bellum norms can be applied not only to international armed conflicts but also to non-international armed conflicts (see, Boon, K. E. (2014). The Application of Jus Post Bellum in Non-International Armed Conflicts. In C. Stahn, J. S. Easterday, \& J. Iverson (Eds.), Jus Post Bellum: Mapping the Normative Foundations (pp. 259-268). Oxford, OX: OUP. p. 265). This article presupposes this observation.

2 Stahn, C. (2007). "Jus ad bellum", "jus in bello" ... "jus post bellum"? — Rethinking the Conception of the Law of Armed Force. European Journal of International Law, 17, 921-943. pp. 940-941.

${ }^{3}$ May suggests, by citing Grotius, that amnesty can be considered as a concrete instrument for reconciliation. On this point, see, May, L. (2014). Jus Post Bellum, Grotius, and Meionexia. In C. Stahn, J. S. Easterday, \& J. Iverson (Eds.), Jus Post Bellum: Mapping the Normative
} 
maintains the necessity of weighing retribution against reconciliation by means of the principle of proportionality, in spite of the conflict. ${ }^{4}$ Yet, he has not considered the particular approaches and consequences of this comparative examination. Bell refers to partial legalization and normative shifts of practice in conflict resolution, which lack formal binding legal status, as lex pacificatoria (law of the peacemakers), and maintains that "a measure of accountability as tempered by a measure of amnesty" can be derived as a quest for what best serves peace in lex. ${ }^{5}$ However, her lex has left indeterminate what degrees of amnesty are permissible. Teitel considers punishment to be potentially complemented by amnesty stimulated by restorative objectives in the context where post bellum inescapably departs from the focus on restoration, ${ }^{6}$ although she has not indicated any specific mode for this complement.

In fact, in international practice, amnesties for serious crimes are granted by truth (and reconciliation) commissions, ${ }^{7}$ despite obligations in treaties and other customary international laws to prosecute wrongdoers for international crimes. ${ }^{8}$ In addition, a conflict exists among tenets regarding whether the International Criminal Court (ICC) has jurisdiction to try certain international crimes if relevant national authorities have granted amnesties for these crimes in advance, because the Rome Statute of the ICC does not have provisions for these amnesties. ${ }^{9}$ These present conditions can be described as the background of the issue raised in the preceding paragraph. ${ }^{10}$

Foundations (pp. 15-25). Oxford, OX: OUP. p. 16; May, L., \& Edenberg, E. (2013). Introduction. In L. May, \& E. Edenberg (Eds.), Jus Post Bellum and Transitional Justice (pp. 1-25). New York, NY: CUP. pp. 2, 4.

${ }^{4}$ May, L. (2013). Jus Post Bellum Proportionality and the Fog of War. European Journal of International Law, 24(1), 315-333. pp. 320-321, 323.

In assessing the value of retribution, May advocates the principle of meionexia which "calls for people to accept less than what they are due if this is necessary for some greater good," referencing impunity in South Africa as an exemplification of this principle. See, May, L. (2012). Jus Post Bellum in the Age of Terrorism: Remarks by Larry May. Am. Soc'y Int'l L. Proc., 106, 332-334. p. 333.

${ }^{5}$ Bell, C. (2013). Peace Settlements and International Law: from Lex Pacificatoria to Jus Post Bellum. In N. White, \& C. Henderson (Eds.), Research Handbook on International Conflict and Security Law: Jus ad Bellum, Jus in Bello, and Jus post Bellum (pp. 499-546). Cheltenham, UK: Edward Elgar. pp. 499, 503, 517-518, 523-524, 525, 544; Bell, C. (2014). Of Jus Post Bellum and Lex Pacificatoria: What's in a Name?. In C. Stahn, J. S. Easterday, \& J. Iverson (Eds.), Jus Post Bellum: Mapping the Normative Foundations (pp. 181-206). Oxford, OX: OUP. pp. 182, 187-188, 191-192, 200-201; the whole range of the study regarding lex pacificatoria is published in Bell, C. (2008). On the Law of Peace: Peace Agreements and the Lex Pacificatoria. Oxford, OX: OUP.

${ }^{6}$ Teitel, R. (2013). Rethinking Jus Post Bellum in an Age of Global Transitional Justice: Engaging with Michael Walzer and Larry May. European Journal of International Law, 24(1), 335-342. p. 337.

${ }^{7}$ See, Hayner, P. B. (2011). Unspeakable Truths: Transitional Justice and the Challenge of Truth Commissions (2nd ed.). New York, NY: Routledge. pp. 104-105.

${ }^{8}$ For instance, in regard to war crimes, see, Jescheck, H. (1982). War Crimes. In R. Dolzer et al. (Eds.), Encyclopedia of Public International Law (Vol. 4, pp. 294-298). Amsterdam: North-Holland. pp. 296-298. However, there is dispute as to whether obligations to prosecute offenders for crimes against humanity can be admitted. On this point, see, Jackson, M. M. (2007). The Customary International Law Duty to Prosecute Crimes Against Humanity: A New Framework. Tul. J. Int'l \& Comp. L., 16, 117-156; Scharf, M. (1996). The Letter of the Law: The Scope of the International Legal Obligation to Prosecute Human Rights Crimes. Law \& Contemp. Probs., 59(4), 41-61; Orentlicher, D. F. (1992). Settling Accounts: The Duty to Prosecute Human Rights Violations of a Prior Regime. Yale L. J., 100, $2537-2615$.

${ }^{9}$ With reference to treatises presenting respective conflicting views: Holtermann, J. H. (2010). The End of 'the end of impunity'? The International Criminal Court and the Challenge from Truth Commissions. Res Publica, 16, 209-225; Roche, D. (2005). Truth Commission Amnesties and the International Criminal Court. Brit. J. Criminol., 45, 565-581; Dugard, J. (2002). Possible Conflicts of Jurisdiction with Truth Commissions. In A. Cassese, P. Gaeta, \& J. R. W. D. Jones (Eds.), The Rome Statute of the International Criminal Court: A Commentary (Vol. 1, pp. 693-704). Oxford, OX: OUP; Wyngaert, C. V., \& Ongena, T. (2002). Ne bis in idem Principle, Including the Issue of Amnesty. In A. Cassese, P. Gaeta, \& J. R. W. D. Jones (Eds.), The Rome Statute of the International Criminal Court: A Commentary (Vol. 1, pp. 705-729). Oxford, OX: OUP; Scharf, M. P. (1999). The Amnesty Exception to the Jurisdiction of the International Criminal Court. Cornell Int'l L. J., 32, 507-527.

${ }^{10}$ As an inquiry into jus post bellum against the background of these current states, there is the article by Ryngaert and Gould, which is a case study of the situation in Uganda as it relates to the principles of complementarity of the ICC and non-penal transitional justice mechanisms, including amnesty, from the perspective of balancing the collision between peace and justice. Ryngaert, C., \& Gould, L. (2011) International Criminal Justice and Jus Post Bellum: The Challenge of ICC Complementarity: A Case-study of the Situation in Uganda. Revue Belge de Droit International, 44, 91-121. 
Empirical and inductive research is required to address this issue. Stahn highlighted the necessity for empirical research to identify the organic principles of jus post bellum. ${ }^{11}$ In contrast, Neff concretely propounded that, "the question of whether there should be rules restricting, or even forbidding, the granting of amnesties to persons accused of violations of the laws of war or of laws protecting fundamental human rights" as a complication requiring an inductive approach. ${ }^{12}$

As a case study involving empirical and inductive research on the above issue, this paper analyzes diplomatic negotiations involved in the process of drafting the Treaty of Peace with Japan, which address the treatment of war criminals. Through these analyses, the author attempts to advance discernible opportunities to balance the antagonism between retribution and reconciliation, or between punishment and amnesty, substantially contributing to answer this article's initial question.

The Treaty of Peace with Japan was selected for this case study because (1) Peace agreements, including peace treaties, as Easterday points out, are "a richer source of norms for jus post bellum than international law," since they facilitate privies of individual conflicts to relatively and profoundly address justice and peace; ${ }^{13}$ (2) According to May and Edenberg, the method of peacemaking in Germany and Japan after the Second World War resulted in discussions about the post bellum norms, thus providing a deeper understanding of these norms $;^{14}$ (3) The Treaty of Peace with Japan is referred to as the treaty of reconciliation: ${ }^{15}$ accordingly, coordination of antagonism between retribution and reconciliation should be based on the preliminary discussions of this treaty; (4) After the treaty's implementation, not only were war crimes suspects not indicted but also all convicted war criminals, who were serving their time in prison, were discharged. Therefore, balance of the collision between punishment and amnesty was apparent in the process of drafting the Treaty of Peace with Japan; and (5) Despite the foregoing pivots of the Treaty, analyses of diplomatic negotiations during its drafting process and their consequent effects have been largely ignored in terms of post bellum norms, with the result that these analyses can be characterized as novel.

\section{Creation of the United States' Methodology for Balance}

\subsection{Pursuing and Securing Retribution}

Although amnesty, ${ }^{16}$ which implies "immunity, or exemption from prosecution or other interference" for war

\footnotetext{
${ }^{11}$ Stahn, C. (2008). Jus Post Bellum: Mapping the Discipline(s). In C. Stahn, \& J. Kleffner (Eds.), Jus Post Bellum - Towards a Law of Transition from Conflict to Peace (pp. 93-112). The Hague. The Netherlands: T·M·C·Asser Press. p. 109.

${ }^{12}$ Neff, S. (2008). Conflict Termination and Peace-making in the Law of Nations: A Historical Perspective. In C. Stahn, \& J. Kleffner (Eds.), Jus Post Bellum - Towards a Law of Transition from Conflict to Peace (pp. 77-91). The Hague, The Netherlands: T·M·C·Asser Press. p. 90.

${ }^{13}$ See, Easterday, J. S. (2014). Peace Agreements as a Framework for Jus Post Bellum. In C. Stahn, J. S. Easterday, \& J. Iverson (Eds.), Jus Post Bellum: Mapping the Normative Foundations (pp. 379-415). Oxford, OX: OUP. pp. 379-380, 382, 386, 412-413. See also, Iverson, J. (2014). Contrasting the Normative and Historical Foundations of Transitional Justice and Jus Post Bellum: Outlining the Matrix of Definitions in Comparative Perspective. In C. Stahn, J. S. Easterday, \& J. Iverson (Eds.), Jus Post Bellum: Mapping the Normative Foundations (pp. 80-101). Oxford, OX: OUP. p. 86; Iverson, J., Easterday, J. S., \& Stahn, C. (2014). Epilogue: Jus Post Bellum-Strategic Analysis and Future Directions. In C. Stahn, J. S. Easterday, \& J. Iverson (Eds.), Jus Post Bellum: Mapping the Normative Foundations (pp. 542-553). Oxford, OX: OUP. p. 545.
}

Note that peace treaties had been an informative and constitutive source of jus post bellum from the 15th to 19th centuries in the discipline of international legal history. See, Lesaffer, R. (2012). Peace treaties and the Formation of International Law. In B. Fassbender, \& A. Peters (Eds.), The Oxford Handbook of the History of International Law (pp. 71-94). Oxford, OX: OUP. pp. 71-72; Lesaffer, R. (2010). Alberico Gentili's ius post bellum and Early Modern Peace Treaties. In B. Kingsbury, \& B. Straumann (Eds.), The Roman Foundations of the Law of Nations: Alberico Gentili and the Justice of Empire (pp. 210-240). New York, NY: OUP. p. 212.

${ }^{14}$ May, \& Edenberg, supra note 3, pp. 14-15.

${ }^{15}$ E.g., John M. Allison, Deputy to Ambassador Dulles of the United States, rephrasing the Treaty of Peace with Japan as "a treaty of reconciliation with Japan.” Allison, J. M. (1973). Ambassador from the Prairie: or Allison Wonderland. Boston: Houghton Mifflin Company. pp. $160,167$.

${ }^{16}$ Amnesty in peace treaties in a broad sense is slightly dissimilar from amnesty prevailingly defined as "the act of a sovereign power officially forgiving certain classes of persons who are subject to trial but have not yet been convicted," (amnesty. In Black's Law Dictionary (10th ed.). (2014). (p. 103). St. Paul, MN: Thomson Reuters. p. 103) in that the former can embrace liberation of war crimes prisoners. It should be noted that the terminology "amnesty" in this article is employed entirely in the sense of the former. 
crimes suspects and convicted war criminals ${ }^{17}$ for the purpose of erasing past wrongs, ${ }^{18}$ had been adopted as a legal principle ${ }^{19}$ and customary practice when negotiating peace treaties, ${ }^{20}$ early drafts of the Treaty of Peace with Japan prepared by the United States during the infancy of the peace process nevertheless absolutely denied amnesty and focused solely on pursuing and securing retribution, following the lead of the Treaty of Peace with Italy. ${ }^{21}$ Specifically, the March 19, 1947 draft manifested the intent to pursue retribution after the conclusion of the peace treaty by stipulating that Japan was obligated to apprehend and turn over ${ }^{22}$ war crimes suspects. ${ }^{23}$ Similarly, the August 5, 1947 and January 8, 1948 drafts advanced the intent to pursue retribution by incorporating the same obligation, ${ }^{24}$ specifying through a clause, referring to amnesty, the intent to secure retribution. Specifically, their respective articles decreed that only the Council of Ambassadors of the Allied Powers possessed the power to grant clemency, reduce sentences, parole, and pardon ${ }^{25}$ ensuring that Japan

${ }^{17}$ Phillipson, C. (1916). Termination of War and Treaties of Peace. New York, NY: E. P. Dutton \& Company. pp. 244, $247,248$.

18 Wolff, C. (1764/1934). Jus Gentium Methodo Scientifica Pertractatum (J. H. Drake, Trans.). Washington, D.C.: the Carnegie Endowment for International Peace. paras. 989, 990, p. 502.; Vattel, E. (1758/1916). Le Droit des Gens, ou Principes de la Loi Naturelle, Appliqués à la Conduite et aux Affaires des Nations et des Souverains (Vol. 4) (C. G. Fenwick, Trans.). Washington, D.C.: the Carnegie Endowment for International Peace. ch. 2, para. 20, p. 351.

19 This property can be exemplified by the theory that the legal effect of amnesty is inevitably yielded even when there is no explicit provision in a peace treaty. On this point, see, Wolff, supra note 18, para. 990, p. 502; Vattel, supra note 18, ch. 2, para. 20, p. 351. See also, Steiger, H. (2004). Peace treaties from Paris to Versailles. In R. Lesaffer (Ed.), Peace Treaties and International Law in European History-From the Late Middle Ages to World War One (pp. 59-99). Cambridge, CB: CUP. p. 84.

${ }^{20}$ Fenwick remarks that it was the custom to insert an amnesty clause in peace treaties before the First World War. Fenwick, C. (1965). International Law (4th ed.). New York: Appleton-Century-Crofts. p. 758.

${ }^{21}$ The United States Department of State analyzed the provision regarding war criminals in the draft of January 8, 1948, as following the pattern established in the Treaty of Peace with Italy. See, Analysis of the Japanese Peace Treaty Draft of January 8, 1948. In United States Department of State. (Ed.), [1948] Foreign Relations of the United States (hereafter FRUS). (Vol. 6). Washington D.C.: U.S. Government Printing Office. p. 660.

${ }^{22}$ Obligation to turn over is deemed to designate that which forces into delivering suspects to the Supreme Commander for the Allied Powers (SCAP) for allowing decisions by the International Prosecution Section of SCAP, which took charge of indictments of category "A" war criminals, and by the Legal Section of SCAP Headquarters, which prosecuted category "B" and "C" criminals. See, Explanatory Notes by Mr. George F. Kennan, March 25, 1948. In [1948] FRUS (Vol. 6). p. 717.

${ }^{23}$ Peace Treaty with Japan. In Records of the Office of Northeast Asian Affairs, Relating to the Treaty of Peace with Japan [microfilm] Subject File, 1945-51 (Lot File 56 D 527). Box no. 1, Folder no. 15, Reel no. 1. (Modern Japanese Political History Materials Room, Japanese National Diet Library).

${ }^{24}$ Draft Treaty of Peace for Japan. In Records of the Office of the Historian. Japanese Peace and Security Treaties, 1946-1952 [microfilm] (Lot File 78 D 173). Box no. 3, Folder no. 8, Reel no. 10. (Modern Japanese Political History Materials Room, Japanese National Diet Library); Draft Treaty of Peace with Japan. In Records of the Office of Northeast Asian Affairs, Relating to the Treaty of Peace with Japan [microfilm] - Subject File, 1945-51 (Lot File 56 D 527). Box no. 5, Folder no. 13, Reel no. 5. (Modern Japanese Political History Materials Room, Japanese National Diet Library); Treaty Draft of 8 Jan 1948. In Records of the Office of the Historian. Japanese Peace and Security Treaties, 1946-1952 [microfilm] (Lot File 78 D 173). Box no. 4, Folder no. 1, Reel no. 11. (Modern Japanese Political History Materials Room, Japanese National Diet Library).

${ }^{25}$ Generally defined, pardon is "[ $\mathrm{t}$ ] he act of an instance of officially nullifying punishment or other legal consequences of a crime." (pardon. In Black's Law Dictionary (10th ed.). (2014). (pp. 1251-1252). St. Paul, MN: Thomson Reuters. p. 1251). Parole is defined as "[t]he conditional release of a prisoner from imprisonment before the full sentence has been served." (parole. In Black's Law Dictionary (10th ed.). (2014). (p. 1292). St. Paul, MN: Thomson Reuters. p. 1292). Clemency is defined as "the power of the President or a governor to pardon a criminal or commute a criminal sentence." (clemency. In Black's Law Dictionary (10th ed.). (2014). (p. 308). St. Paul, MN: Thomson Reuters. p. 308.)

Given that in-depth contents of amnesty in peace treaties have not been explained despite their formal definition as a deed for oblivion paraphrased by pardon or clemency (see, Phillipson, supra note 17, p. 244; Zayas, A. (1992). Amnesty Clause. In P. Macalister-Smith et al. (Eds.), Encyclopedia of Public International Law (Vol. 1, pp. 148-151). Amsterdam: North-Holland. p. 148; Seibert-Fohr, A. (2012). Amnesties. In K. Kaiser et al. (Eds.), The Max Planck Encyclopedia of Public International Law (Vol. 1, pp. 358-365). New York, NY: OUP. pp. 358-359), at least in this case of aiming to erase past history (Yoshida, S. (1973). The Yoshida Memoirs: the Story of Japan in Crisis (K. Yoshida, Trans.). Westport, Connecticut: Greenwood Press. pp. 114-115), pardon and clemency in the drafts of, or in the Treaty of Peace with Japan, can be considered an embodiment of amnesty in peace treaties. 
thoroughly executed the sentences of convicted war criminals. ${ }^{26}$ In this vein, the United States divested Japan of the power to grant amnesty ${ }^{27}$ and precluded reconciliation, which was the end of amnesty; ${ }^{28}$ therefore, it solely attempted to secure retribution.

\subsection{Introduction of Reconciliation and Alleviation of Retribution}

After closure of examination by the International Military Tribunal for the Far East, despite the abovementioned efforts in pursuit of retribution, the construction of established facts ("de facto peace"), including requests for early completion of war crimes trials and screening of war crimes suspects who can be discharged, proceeded under the guidance of George F. Kennan, Director of the Policy Planning Staff of the United States Department of State. Kennan's March 25, 1948 report advocated (1) that the trials of category "A" suspects should be terminated early; (2) that all category "B" and "C" suspects should be screened with a view to releasing those whose cases were not intended to be prosecuted by the Allied Powers; and (3) that the other "B" and "C" suspects supposed to be indicted should face expeditious trials. ${ }^{29}$ Documents based upon this report and adopted by the United States National Security Council (NSC) indicated their contemplation of gathering established facts $^{30}$ ("de facto peace") ${ }^{31}$ in an effort to assist the United States' policy that it "should try to clear away during this intervening period as many as possible of the matters which might otherwise be expected to enter into the treaty of peace, ${ }^{32}$ by duplicating Kennan's proposal to (1) determine the trial of "A" suspects; (2) institute and

Clemency can certainly imply "[m]ercy or leniency," (clemency, supra note 25, p. 308), but the equivalents for "clemency" in the Treaty of Peace with Japan are "grâces" in French and “赦免[shamen]" in Japanese, which are equally authentic and mean absolution of guilt. (Traite de Paix avec le Japon. In Records of the Office of the Historian. Japanese Peace and Security Treaties, 1946-1952 [microfilm] (Lot File 78 D 173). Box no. 4, Folder no. 14, Reel no. 11. (Modern Japanese Political History Materials Room, Japanese National Diet Library) (in French); 日本国との平和条約. In Records of the Office of the Historian. Japanese Peace and Security Treaties, 1946-1952 [microfilm] (Lot File 78 D 173). Box no. 4, Folder no. 14, Reel no. 11. (Modern Japanese Political History Materials Room, Japanese National Diet Library) (in Japanese)). Thus, clemency in every draft of the Treaty of Peace with Japan should stand for the forgiveness of crimes.

${ }^{26}$ Article 20 of the August 5 draft provided that, "Japan undertakes to execute fully the sentences imposed ... by Allied military tribunals in Japan on persons convicted ... The power to pardon, parole, reduce sentences, and grant clemency shall be lodged with the Council of Ambassadors for Japan.” Draft Treaty of Peace for Japan, supra note 24; Draft Treaty of Peace with Japan, supra note 24.

Article 23 of the January 8 draft provided that, "Japan undertakes to execute fully the sentences imposed by Allied military tribunals on persons convicted ... The power to grant clemency, reduce sentences, parole and pardon shall be lodged with the Council of Ambassadors for Japan.” Treaty Draft of 8 Jan 1948, supra note 24.

${ }^{27}$ The power to grant amnesty in peace treaties can be exercised by sovereign states (Japan, in this section's context) by nature. See, amnesty clause. In Black's Law Dictionary (10th ed.). (2014). (p. 103). St. Paul, MN: Thomson Reuters. p. 103.

${ }^{28}$ E.g., Lesaffer, R. (2002). An Early Treatise on Peace Treaties: Petrus Gudelinus between Roman Law and Modern Practice. J. Legal Hist., 23, 223-252. p. 233.

${ }^{29}$ Report by the Director of the Policy Planning Staff (Kennan). In [1948] FRUS (Vol. 6). p. 696. On the main reasons for these suggestions, see, Explanatory Notes by Mr. George F. Kennan, March 25, 1948, supra note 22, p. 718.

${ }^{30}$ Shigeru Yoshida, Prime Minister of Japan, referred to elaboration of situations anticipated, stipulating in the peace treaty by the Allied Powers as the construction of established facts. Yoshida, S. (1998). Kaisō Jūnen [Ten Years Memoirs] (Vol. 3). Tokyo: Chuokoron-sha, INC. p. 25 (in Japanese).

31 The explanatory study of the July 12, 1951 draft of the peace treaty mentioned that, "during the occupation, extending over six years, de facto peace measures were taken one after another and that a large part of the various problems connected with the war's aftermath have been settled." Explanatory Study of Draft Japanese Peace Treaty. In Records of the Office of the Historian. Japanese Peace and Security Treaties, 1946-1952 [microfilm] (Lot File 78 D 173). Box no. 1, Folder no. 6, Reel no. 8. (Modern Japanese Political History Materials Room, Japanese National Diet Library). p. 5; Nihon koku to no heiwa jōyaku sōan no kaisetsu [Explanatory Study of Draft Japanese Peace Treaty]. In Ministry of Foreign Affairs of Japan. (Ed.). (2007). Documents on Japanese Foreign Policy: Treaty of Peace with Japan Negotiation with the United States. Tokyo: Ministry of Foreign Affairs of Japan (hereafter DJFP: Negotiation with the US). p. 672 (in Japanese).

32 On NSC13 of June 2, 1948, see, Recommendations With Respect to U.S. Policy Toward Japan, June 2, 1948. In P. Kesaris (Ed.). (1980). Documents of the National Security Council [microfilm] (Vol. 1). Washington, D.C.: University Publications of America. A:I:0293, p. 1. On NSC13/1 of September 24, 1948, see, Recommendations With Respect to U.S. Policy Toward Japan, September 24, 1948. In P. Kesaris (Ed.). (1980). Documents of the National Security Council [microfilm] (Vol. 1). Washington, D.C.: University Publications of America. A:I:0301, p. 1. On NSC13/2 of October 7, 1948, see, Recommendations With Respect to U.S. Policy Toward Japan, October 7, 1948. In P. Kesaris (Ed.). (1980). Documents of the National Security Council [microfilm] (Vol. 1). Washington, D.C.: University Publications of America. A:I:0317, p. 1; Note by the NSC Executive Secretary (Souers) to President Truman. In [1948] FRUS (Vol. 6). p. 858. On NSC13/3 of May 6, 
conclude the trials of "B" and "C" suspects at the earliest possible date; (3) and screen apprehended suspects for early release. ${ }^{33}$

According to these NSC documents, de facto amnesty arose by means of the expiration of war crimes trials, discontinuation of new indictments of "A" suspects, and emancipation of convicted war criminals already in prison. In early 1948, the decision to no longer prosecute "A" suspects had already been announced by the Supreme Commander for the Allied Powers (SCAP) and approved by the Far Eastern Commission, ${ }^{34}$ and in October, 1949, SCAP disclosed the completion of all scheduled "B" and "C" war crimes trials in Japan. ${ }^{35}$ In January, 1950, William J. Sebald's, Acting Political Adviser to SCAP, recommended against the government's proposal to continue capturing, turning over, and trying war crimes suspects, a recommendation that was approved by MacArthur and the Department of State, ${ }^{36}$ and finally, on March 7, 1950, SCAP issued a circular establishing a uniform system for release, including confinement credit, good time credit, and parole, which were applicable to all convicted war criminals serving sentences in Japan. ${ }^{37}$

Apart from congeries of de facto amnesty and the view to codify the abovementioned movement, ${ }^{38}$ the draft of the Treaty of Peace with Japan gradually came to include reconciliation by virtue of vesting the power to grant amnesty with Japan while alleviating retribution by eliminating Japan's obligation to arrest and turn over suspects and absolving the complete administration of penalties. Indeed, the September 7, 1949 draft providing Japan's complete sentence, resolved to secure retribution, and therefore, did not mandate reconciliation as a condition of amnesty. ${ }^{39}$ On the one hand, similar to the January 8, $1948 \mathrm{draft}$, the October 13, $1949 \mathrm{draft}^{40}$ prescribed Japan's obligation to apprehend and turn over war crimes suspects to the Allied Powers, ${ }^{41}$ followed by appropriate punishments administered by Japan. ${ }^{42}$ On the other hand, unlike the January draft, the October 13

1949, see, Recommendations With Respect to U.S. Policy Toward Japan, May 6, 1949. In P. Kesaris (Ed.). (1980). Documents of the National Security Council [microfilm] (Vol. 1). Washington, D.C.: University Publications of America. A:I:0326, p. 1; Report by the National Security Council on Recommendations With Respect to United States Policy Toward Japan. In [1949] FRUS (Vol. 7). p. 730.

33 On NSC13 of June 2, 1948, see, Recommendations With Respect to U.S. Policy Toward Japan, June 2, 1948, supra note 32, pp. 5-6. On NSC13/1 of September 24, 1948, see, Recommendations With Respect to U.S. Policy Toward Japan, September 24, 1948, supra note 32, p. 9. On NSC13/2 of October 7, 1948, see, Recommendations With Respect to U.S. Policy Toward Japan, October 7, 1948, supra note 32, p. 5; Note by the NSC Executive Secretary (Souers) to President Truman, supra note 32, p. 862. On NSC13/3 of May 6, 1949, see, Recommendations With Respect to U.S. Policy Toward Japan, May 6, 1949, supra note 32, p. 6; Report by the National Security Council on Recommendations With Respect to United States Policy Toward Japan, supra note 32, pp. 734-735.

34 Fearey, R. A. (1972). The Occupation of Japan: Second Phase: 1948-50. Westport, Connecticut: Greenwood Press. p. 18.

35 Ibid., p. 20; Commentary on 1947 Treaty. In Records of the Office of Northeast Asian Affairs, Relating to the Treaty of Peace with Japan [microfilm] - Subject File, 1945-51 (Lot File 56 D 527). Box no. 1, Folder no. 8, Reel no. 1. (Modern Japanese Political History Materials Room, Japanese National Diet Library).

36 Ibid.

37 Fearey, supra note 34, p. 194; Commentary on 1947 Treaty, supra note 35.

38 With reference to an attempt to stipulate actuality during the period of occupation, it is noteworthy that Dunn described the October 13 , 1949 draft shown below as "thoroughly realistic." Dunn, F. S. (1963). Peace-Making and the Settlement with Japan. Princeton, NJ: Princeton University Press. p. 86.

39 Article 15 provided that, "Japan undertakes to execute fully the sentences imposed by Allied military tribunals on persons convicted of war crimes or crimes against peace or humanity who are incarcerated in Japan." Treaty of Peace with Japan. In Records of the Office of Northeast Asian Affairs, Relating to the Treaty of Peace with Japan [microfilm] - Subject File, 1945-51 (Lot File 56 D 527). Box no. 6, Folder no. 2, Reel no. 6. (Modern Japanese Political History Materials Room, Japanese National Diet Library). p.7.

40 This draft is not recorded in Foreign Relations of the United States. See, Memorandum by Mr. Robert A. Fearey, of the Office of Northeast Asian Affairs, to the Deputy Director of the Office (Allison). In [1949] FRUS (Vol. 7). p. 877, n. 1.

${ }^{41}$ Article 18 provided that, "Japan shall take all necessary steps to ensure the apprehension and surrender to the appropriate Allied and Associated Power [sic] for trial of persons within Japanese jurisdiction ..." Treaty of Peace with Japan. In Records of the Office of the Historian. Japanese Peace and Security Treaties, 1946-1952 [microfilm] (Lot File 78 D 173). Box no. 1, Folder no. 6, Reel no. 8. (Modern Japanese Political History Materials Room, Japanese National Diet Library). p. 9.

42 Article 20 provided that, "Japan undertakes to execute fully the sentences imposed by Allied military tribunals on persons convicted ..." Ibid., p. 10. 
draft stipulated Japan's right to exercise the authority to grant amnesty after approval from the Allied Powers. ${ }^{43}$ Thus, with survival of the pursuit and security of retribution, the October 13 draft introduced reconciliation by vesting Japan with the power to grant amnesty. The November 2 draft permuted the order of the articles, but nonetheless, provided the continued obligation to apprehend and turn over even after specifying the approval by the Allied Powers to concede power to Japan to grant amnesty, ${ }^{44}$ highlighting the considerations of reconciliation. Although the introduction of reconciliation was being promoted in this vein, the modification in the pursuit and security of retribution remained unrealized. ${ }^{45}$ Yet, the December 29 draft omitted the clause obligating Japan to arrest and turn over suspects and only stipulated the partial execution of sentences ${ }^{46}$ and amnesty power be granted to Japan, with the consent of the Allied Powers. ${ }^{47}$ Thus, while the United States introduced reconciliation, it renounced pursuit of retribution and agreed on the moderate security of retribution.

\subsection{The United States' Methodology}

For the purpose of securing retribution and the potential fruition of reconciliation, the United States devised a methodology to restrain reconciliation so that retribution might be secured to the extent of restriction on reconciliation. The August 17, 1950 draft treaty, enunciating Japan's deference to the sentences, ${ }^{48}$ prescribed that the power to grant amnesty might be wielded by Japan only insofar as the Allied and Associated Powers conceded. ${ }^{49}$ At this point, by conditioning the right to exercise the authority of granting amnesty, the trend toward restraining reconciliation could be observed. Moreover, despite omitting the clause with respect to rulings, the September 11 draft provided for Japan's right to exercise its power of granting amnesty in collaboration with the Allied Powers. ${ }^{50}$ Accordingly, the United States restricted the manner in which Japan could employ its power to grant amnesty by virtue of requiring joint application, although it accepted the power to grant amnesty itself; hence, it created the methodology to restrain reconciliation and secure retribution to the extent of restriction on reconciliation.

${ }^{43}$ Article 20 provided that, "The power to grant clemency, reduce sentences, parole and pardon may be exercised by Japan with the approval of the Government or Governments which imposed the sentence in each instance. In the case of the persons sentenced by the International Military Tribunal for the Far East, such power may be exercised by Japan with the approval of a majority of the Governments represented on the Tribunal." Ibid.

${ }^{44}$ Treaty of Peace with Japan. In Records of the Office of Northeast Asian Affairs, Relating to the Treaty of Peace with Japan [microfilm] Subject File, 1945-51 (Lot File 56 D 527). Box no. 6, Folder no. 3, Reel no. 6. (Modern Japanese Political History Materials Room, Japanese National Diet Library). pp. 11-12; Treaty of Peace with Japan. In Records of the Office of Northeast Asian Affairs, Relating to the Treaty of Peace with Japan [microfilm] - Subject File, 1945-51 (Lot File 56 D 527). Box no. 6, Folder no. 11, Reel no. 6. (Modern Japanese Political History Materials Room, Japanese National Diet Library). pp. 11-12.

${ }^{45}$ It is noteworthy that Sebald, Ambassador of the United States and Acting Political Adviser to SCAP, argued against a punitive attitude toward Japan in the November 2 draft and sent a comment about the patronizing tone of this draft. Sebald, W. J. (1965). With MacArthur in Japan: A Personal History of the Occupation. New York, NY: W.W. Norton. p. 249.

${ }^{46}$ Article 14 provided that, "Japan undertakes to execute the sentences ..." Draft Treaty of Peace with Japan. In Records of the Office of Northeast Asian Affairs, Relating to the Treaty of Peace with Japan [microfilm] - Subject File, 1945-51 (Lot File 56 D 527). Box no. 6, Folder no. 4, Reel no. 6. (Modern Japanese Political History Materials Room, Japanese National Diet Library). p. 11; Draft Treaty of Peace with Japan. In Records of the Office of the Historian. Japanese Peace and Security Treaties, 1946-1952 [microfilm] (Lot File 78 D 173). Box no. 2, Folder no. 8, Reel no. 9. (Modern Japanese Political History Materials Room, Japanese National Diet Library). p. 11.

${ }^{47}$ Article 14 provided that, "The power ... may be exercised by Japan upon the approval of the Government or Governments which imposed the sentence in each instance ..." Draft Treaty of Peace with Japan (Records of the Office of Northeast Asian Affairs), supra note 46, p. 11; Draft Treaty of Peace with Japan (Records of the Office of the Historian), supra note 46, p. 11.

${ }^{48}$ Paragraph 15 provided that, "Japan will respect the sentences imposed by military tribunals of the Allied and Associated Powers on persons who are incarcerated in Japan.” Japan Treaty Draft by Mr. Dulles. In Records of the Office of the Historian. Japanese Peace and Security Treaties, 1946-1952 [microfilm] (Lot File 78 D 173). Box no. 1, Folder no. 2, Reel no. 7. (Modern Japanese Political History Materials Room, Japanese National Diet Library).

${ }^{49}$ Paragraph 15 provided that, "The power to grant clemency, reduce sentences, parole and pardon may be exercised by Japan only with the approval of the Government or Governments which imposed the sentence in each instance." Ibid.

${ }^{50}$ Paragraph 16 provided that, "The power to grant clemency, reduce sentences, parole and pardon ... may be exercised jointly by Japan and the Government or Governments which imposed the sentence in each instance. In the case of the persons sentenced by the International Military Tribunal for the Far East, such power may be exercised jointly by Japan and a majority of the Governments represented on the Tribunal.” Draft of a Peace Treaty With Japan. In [1950] FRUS (Vol. 6). pp. 1299-1300. 


\section{Consultation ${ }^{51}$ between the United States and Japan}

\subsection{Amnesty for Convicted War Criminals}

The United States instructed Japan on securing retribution for convicted war criminals only at an abstract level without providing any drafts of the peace treaty; hence, the United States' concrete methodology did not succeed in the agenda between the United States and Japan. According to the report drafted by the Ministry of Foreign Affairs of Japan and digested conversations between relevant officers of the United States Department of State's Office of Northeast Asian Affairs and those who were in the Ministry of Foreign Affairs of Japan from late September to mid-October $1950,{ }^{52}$ Robert A. Fearey, a member of the Office of Northeast Asian Affairs, explained that with regard to the political clauses in the drafts, the United States was determined to secure the execution of punishment of convicted war criminals even after the ratification of the Treaty of Peace with Japan, ${ }^{53}$ and on January 26, 1951, although Japan received the agenda that included the item regarding war criminals, the sole focus was on jurisdiction over the convicted. ${ }^{54}$

Thereupon, Japan requested that the United States give the Japanese government the power to grant amnesty to war crimes suspects and convicted war criminals. On January 30, Shigeru Yoshida, Prime Minister of Japan, handed his "Suggested Agenda" (his personal remarks) ${ }^{55}$ to the United States requesting, (1) "No more new arraignments" and (2) "An amnesty on the occasion of the conclusion of the peace treaty.",56"

In reply, the United States informed Japan about the methodology for attempting reconciliation. During talks with Yoshida on January 31, John F. Dulles, Consultant to the Secretary of State and Special Representative of the President of the United States, responded to Yoshida's views, agreeing with the proposal of no additional indictments, but rejecting general amnesty for convicted war criminals, countering with case-by-case decisions

${ }^{51}$ The United States conceived Japan not as the party in negotiation but as the party in consultation. On this point, Kumao Nishimura, Director of the Bureau of Treaties of the Ministry of Foreign Affairs of Japan, mentioned that talks with the United States were not negotiations in a strict sense but were consultations. See, Ministry of Foreign Affairs of Japan. (Ed.). (2002). Documents on Japanese Foreign Policy: Records Related to the Conclusion of Treaty of Peace with Japan (hereafter DJFP: Records) (Vol. 2). Tokyo: Ministry of Foreign Affairs of Japan. p. 9 (in Japanese). In this regard, on January 25, 1951, John F. Dulles, Consultant to the Secretary of State and Special Representative of the President of the United States, stated that “... I have returned to discuss the situation further at Tokyo for we look upon Japan as a party to be consulted ..." 1951 nen 1 gatsu 25 nichi Haneda kukō ni okeru Dulles tokushi no sutētomento [Ambassador Dulles' statement at Haneda Airport on January 25, 1951]. In DJFP: Records (Vol. 2). p. 109.

52 On the course of preparing this report, see, Ministry of Foreign Affairs of Japan. (Ed.). (2002). DJFP: Records (Vol. 1). Tokyo: Ministry of Foreign Affairs of Japan. p. 608 (in Japanese).

${ }^{53}$ Kōwa mondai ni kansuru bei kokumushō kakarikan no danwa ni kansuru ken [On conversations with the relevant officers of the Department of State with a bearing on the matters of peace]. In DJFP: Records (Vol. 1). p. 776 (in Japanese).

${ }^{54}$ Suggested Agenda. In DJFP: Records (Vol. 2). p. 122; Suggested Agenda. In DJFP: Records (Vol. 1). p. 80.

${ }^{55}$ In this document, it was noted that "I am setting forth below my private views. -S[higeru]. Y[oshida]." Suggested Agenda. In DJFP: Records (Vol. 2). p. 145.

${ }^{56}$ Ibid., p. 149; Suggested Agenda. In DJFP: Records (Vol. 1). p. 85. Note that although Yoshida's "Suggested Agenda" itself is recorded in Foreign Relations of the United States, contents below VII including "XII. War criminals" is not inserted in. See, Undated Memorandum by the Prime Minister of Japan (Yoshida). In [1951] FRUS (Vol. 6). pp. 833-835.

Japan's movements up to "Suggested Agenda" were as follows: (1) Japan had been apprehensive of the maintenance of measures for war criminals in the "Conceivable outline of the Treaty of Peace with Japan" of September 1950 (Tainichi heiwa jōyaku sōtei taikō [Conceivable outline of the Treaty of Peace with Japan]. In DJFP: Records (Vol. 1). p. 666 (in Japanese)); "Framework of the draft of Japanese Peace Treaty by the United States" of October 2 (Beikoku no tainichi heiwa jōyaku an no kōsō [Framework of the draft of Japanese Peace Treaty by the United States]. In DJFP: Records (Vol. 1). p. 643 (in Japanese)); "Problems with various reformations for democratizing Japan" of November 9 (Nihon minshuka no tameno shokaikaku ni okeru mondaiten [Problems with various reformations for democratizing Japan]. In DJFP: Records (Vol. 1). p. 745 (in Japanese)). (2) With the result that Japan had considered the desire for amnesty for the suspected and convicted war criminals in "Draft of policies on Japan's requests corresponding to the framework of the draft of the Japanese Peace Treaty of the United States" of October 4 (Beikoku no tainichi heiwa jōyaku an no kōsō ni taiō suru wagahō yōbō hōshin (an) [Draft of policies on Japan's requests corresponding to the framework of the draft of the Japanese Peace Treaty of the United States]. In DJFP: Records (Vol. 1). p. 647 (in Japanese)); "Draft of the document of statement to the United States" of October 4 (Taibei chinjyutsu sho (an) [Draft of the document of statement to the United States]. In DJFP: Records (Vol. 1). p. 656 (in Japanese)). (3) After Japan's January 26, 1951 receipt of the agenda, drawing on "Draft of the document of statement to the United States," the drafts of Yoshida's "Suggested Agenda" had been prepared. See, Ministry of Foreign Affairs of Japan, supra note 51, pp. 123-142 (in English and Japanese). 
on discrete amnesty rulings in proportion with crimes committed. ${ }^{57}$ The United States delivered the "Provisional Memorandum," prepared by the Dulles Mission on February 3, to Japan on February $5 .^{58}$ This memorandum endorsed amending the power to grant amnesty for convicts to be a joint exercise to include Japan and the governments of the Allied Powers; ${ }^{59}$ thus, the United States revealed its methodology to restrain reconciliation by means of conditioning the manner of granting amnesty and to secure retribution to the extent of restriction on reconciliation.

\subsection{Amnesty for War Crimes Suspects}

In contrast, the February 3, 1951 provisional memorandum made no mention of amnesty for war crimes suspects, resulting in Japan's call to include the explicit provision for this amnesty. On February 6, at the administration-level talks with the United States, the Japanese government expressed its opinion on the provisional memorandum, stating that, "It is desired a clause be inserted, putting an end to prosecution of new cases, ${ }^{, 60}$ in the peace treaty. ${ }^{61}$

Thereupon, at the February 7 talks between Yoshida and Dulles, Dulles offered an account of his methodology regarding amnesty for war crimes suspects. Concretely, Dulles exhibited his understanding that de facto amnesty could be primarily considered and that, secondarily, the United States would be willing to consider inserting an amnesty clause if it appeared that war crimes trials could not be completed by the time of the conclusion of the peace treaty. ${ }^{62}$

From the facts presented above, it seems reasonable to suppose that the United States aimed only for reconciliation by virtue of de facto amnesty, jettisoning pursuit of retribution, at least insofar as war crimes suspects were concerned. ${ }^{63}$ Consequently, what should have been an issue for the United States in drafting the

571951 nen 1 gatsu 31 nichi dai 2 ji kaidan memo [Memorandum of the second talks between Yoshida and Dulles on January 31, 1951]. In DJFP: Records (Vol. 2). p. 160 (in Japanese). See also, 1951 nen 2 gatsu 13 nichi duke sōri ni teishutsu shita jōyakukyokuchō no kaidan keika hōkokusho [Report submitted to Prime Minister by Director of the Bureau of Treaties on February 13, 1951, as to the course of the talks with the Dulles Mission]. In DJFP: Records (Vol. 2). pp. 289-290 (in Japanese). Note that no memorandum of the conversation held on January 31 between Dulles and Yoshida has been found in files of the Department of State of the United States, and in Foreign Relations of the United States. See, Memorandum by Mr. Robert A. Fearey of the Office of Northeast Asian Affairs. In [1951] FRUS (Vol. 6). p. 839, n. 5 .

${ }^{58}$ Kari oboegaki an [Provisional Memorandum]. In DJFP: Negotiation with the US. p. 229, n. 1 (in Japanese). See also, Ministry of Foreign Affairs of Japan, supra note 51, pp. 54, 59 (in Japanese).

${ }^{59}$ Paragraph (e) in Political and Economic Clauses provided that, "The power to grant clemency, reduce sentences, parole and pardon ... would be exercised jointly by Japan and the Government or Governments ...” Memorandum Prepared by the Dulles Mission. In [1951] FRUS (Vol. 6). p. 851; Provisional Memorandum. In DJFP: Records (Vol. 2). pp. 205-206; Provisional Memorandum. In DJFP: Records (Vol. 1). p. 93.

This paragraph should be considered to restrain reconciliation slightly stronger than that of the September 11, 1950, draft, in that, compared to the latter, which adopted the diction, "The power ... may be exercised jointly," the former altered it to "The power ... would be exercised jointly;" therefore, the joint right to exercise the power to grant amnesty was determined. Along the same lines, given that Dulles admitted in an interview to the Associated Press on February 5, 1951, that Japan had no power to alter the verdicts of war trials and suggested his intent to restrain not the manner of granting amnesty but the power to grant amnesty itself, the direction toward the intensification of the restriction on reconciliation and the enlargement of securing retribution could be found. See, e.g., Dulles Interview (Brines-AP) by Russell Brines. In DJFP: Records (Vol. 2). pp. 347-348.

${ }^{60}$ On Provisional Memorandum. In DJFP: Records (Vol. 2). p. 212; Unsigned Japanese Government Memorandum. In [1951] FRUS (Vol. 6). p. 860. On the original draft of this document, see, "Kari oboegaki" ni taisuru obuzabēshon gen-an [Original draft of the observations on "Provisional Memorandum"] In DJFP: Records (Vol. 2). p. 214 (in Japanese).

${ }^{61}$ In the official documents of the Ministry of Foreign Affairs of Japan, it is recorded that the relevant officers of the United States catered the request of war criminals at the talks. See, 1951 nen 2 gatsu 6 nichi no kaidan memo [Memorandum of the talks on February 6, 1951]. In DJFP: Records (Vol. 2). p. 216 (in Japanese). However, there are no records with respect to the specific contents of the talks in Foreign Relations of the United States. See, Unsigned Japanese Government Memorandum, supra note 60, p. 860, n. 1.

${ }^{62}$ Memorandum of Conversation, by Mr. Robert A. Fearey of the Office of Northeast Asian Affairs. In [1951] FRUS (Vol. 6). p. 867. Dulles' view was discussed at the Dulles Mission staff meeting before the talks. See, Memorandum by Mr. Robert A. Fearey of the Office of Northeast Asian Affairs. In [1951] FRUS (Vol. 6). p. 864.

${ }^{63}$ However, it needs to be pointed out that there could be subtle differences with respect to Dulles' explanation between the diplomatic correspondence of the United States and that of Japan. In the latter, it is merely documented that Dulles remarked that new war crimes trials 
Treaty of Peace with Japan was the restriction on reconciliation and security of retribution for convicted war criminals. Since the present paper is conducting a case study on balancing the conflict between retribution and reconciliation, the focus here should be on retribution for convicted war criminals and not for war crimes suspects who were granted de facto amnesty.

As a result of the consultation with Japan, the United States obtained Japan's consent to the provisional memorandum unveiling its mechanism for securing retribution for the convicted, and on February 9, both states initialed the five documents, which included the February 8 provisional memorandum, ${ }^{64}$ representing the momentary achievement of an understanding. ${ }^{65}$

\section{Discord between the United States and the United Kingdom}

\subsection{Dispute over Methodology for Retribution}

Prior to communicating with Japan, the United States had informed the United Kingdom about adopting the mechanism of confining the exercising fashion of Japan's power to grant amnesty as the methodology for balance. The United Kingdom, on the other hand, proposed a completely different methodology seeking exhaustive security of retribution by obligating Japan to execute convictions. On January 12, 1951, John F. Dulles of the United States delivered the Eight-point Memorandum to Oliver S. Franks, British Ambassador to the United States, stating that the power to grant amnesty to prisoners was determined to be employed collaboratively between Japan and the Allied Powers ${ }^{66}$ disclosing the United States' methodology limiting the exercise of the power to grant amnesty and securing retribution to the extent of restriction on reconciliation. Yet, in the March 12 aide-mémoire, addressed to the United States, the United Kingdom claimed, without mentioning the authority to confer amnesty, that Japan should be obligated to administer punishment, ${ }^{67}$ advancing its methodology to secure retribution. ${ }^{68}$ By this reciprocation, the violent collision of the two methodologies emerged.

The United States' first reaction to this dissension was to define the sixth point of the Eight-point Memorandum,

were not allowed, even if a provision for ending prosecution was not added, with the result that it is possible to consider that Japan grasped the elucidation by Dulles as one implying the tacit legal effect of de jure amnesty for suspects. See, 1951 nen 2 gatsu 7 nichi no sōri Dulles kaidan memo [Memorandum of the talks between Prime Minister and Dulles on February 7, 1951] In DJFP: Records (Vol. 2). pp. 235-236 (in Japanese); 1951 nen 2 gatsu 13 nichi duke sōri ni teishutsu shita jōyakukyokuchō no kaidan keika hōkokusho [Report submitted to Prime Minister by Director of the Bureau of Treaties on February 13, 1951, as to the course of the talks with the Dulles Mission], supra note 57, p. 297 (in Japanese). Note that there are also distinctions with regard to Yoshida's utterance about the Soviet Union.

The above inference might be supported by Japan's explanatory note of the July 12, 1951 treaty draft, which commented briefly on the theory of the tacit legal effect of amnesty for war crimes suspects. See, Explanatory Study of Draft Japanese Peace Treaty, supra note 31, p. 24; Nihon koku to no heiwa jōyaku sōan no kaisetsu [Explanatory Study of Draft Japanese Peace Treaty], supra note 31, p. 683 (in Japanese).

${ }^{64}$ Provisional Memorandum. In DJFP: Records (Vol. 2). p. 255. This memorandum was exactly the same as that of February 3.

${ }^{65}$ Ministry of Foreign Affairs of Japan, supra note 51, pp. 97-98 (in Japanese).

${ }^{66}$ The sixth point provided that, "The power ... would be exercised jointly by Japan and the Government or Governments ..." See, Memorandum of Conversation, by the Special Assistant to the Consultant (Allison). In [1951] FRUS (Vol. 6). p. 796. This memorandum was identical to the provisional memorandum of February 3 handed to Japan on February 5. However, the provisional draft of the peace treaty of March 9 and 12 provided that "The power ... may be exercised jointly by Japan and the Government or Governments ..." adopting the same expressions as the draft of September 11, 1950; therefore, the United States lacked the uniformity between the memoranda for external negotiations and the domestic drafts of its government. See, Provisional Draft of a Japanese Peace Treaty (March 9, 1951). In Records of the Office of the Historian. Japanese Peace and Security Treaties, 1946-1952 [microfilm] (Lot File 78 D 173). Box no. 2, Folder no. 8, Reel no. 9. (Modern Japanese Political History Materials Room, Japanese National Diet Library). p. 6; Provisional Draft of a Japanese Peace Treaty (March 12, 1951). In Records of the Office of the Historian. Japanese Peace and Security Treaties, 1946-1952 [microfilm] (Lot File 78 D 173). Box no. 2, Folder no. 8, Reel no. 9. (Modern Japanese Political History Materials Room, Japanese National Diet Library). p. 6.

${ }^{67}$ Paragraph 7 (iii) provided that, "An obligation should be laid upon the Japanese Government to ensure that, subject to normal remissions for good conduct, war criminals in Japan sentenced to terms of imprisonment before the Peace Treaty takes effect should serve the sentences imposed upon them by duly constituted War Crimes Courts." See, The British Embassy to the Department of State. In [1951] FRUS (Vol. 6). p. 911.

${ }^{68}$ This methodology had been recommended by the British government in "Japanese Peace Treaty: General" of December 19, 1950. See, Japanese Peace Treaty: General (C.P. (50) 323, the United Kingdom National Archives). pp. 2-3. 
which could, on its face, be construed as giving Japan the power to grant amnesty, but clarifying its design to condition the manner and use of the power to grant amnesty and secure retribution. The second reaction by the United States was to redraft the Treaty of Peace with Japan, with the result that it adopted the clause, which unequivocally grants the power to grant amnesty as an exception to the principle of securing retribution. Initially, in the March 13, 1951 aide-mémoire addressed to the United Kingdom, the United States remarked that it believed that the Japanese government should not be able to grant amnesty to convicted war criminals, unless by agreement of the Allied Powers, ${ }^{69}$ declaring the substance of the methodology enunciated in the Eight-point Memorandum restrictive in invoking amnesty. Second, the provisional draft presented by the United States to the United Kingdom on March $23^{70}$ adopted a negative tone, which provided that Japan would be unable to use the power to grant amnesty, except in collaboration with the Allied Powers. ${ }^{71}$ Therefore, not only did the United States' methodology for securing retribution become more definite on its face but it also strengthened the restraint on reconciliation by virtue of thrusting the user of amnesty into the exception and positioning the security of retribution as the principle over that which had been hitherto adopted. ${ }^{72}$

The United Kingdom, without considering its relationship with the United States, ${ }^{73}$ delivered its provisional draft of the Treaty of Peace with Japan to the United States. Despite arranging an evident compromise with the methodology advocated by the United States ${ }^{74}$ this provisional memorandum imposed comparatively rigorous restrictions against the exercise and components of the power to grant amnesty by Japan and leaned toward securing retribution more than the methodology of the United States. Specifically, the April 7, 1951 British provisional draft, handed to the United States on April 9, had been ready since February ${ }^{75}$ and ascertained the security of retribution by its first sentence under Article 21, which stipulated the acknowledgment of the judgments and performance of the convictions. ${ }^{76}$ Further, the second sentence of Article 21 not only placed a harsh restriction on the use of power to grant amnesty by positioning the joint right to exercise this power as one of Japan's legalities, but also assigned a limit to the constituents of this power by omitting the word "pardon" from a listing of the modes of release. ${ }^{77}$

${ }^{69}$ The Department of State to the British Embassy. In [1951] FRUS (Vol. 6). p. 922. However, with reference to the war criminals, the United States' provisional draft of the peace treaty of March 16 adopted the identical clause with the draft of September 11, 1950, differing from the sixth point of the Eight-point Memorandum. See, Provisional Draft of a Japanese Peace Treaty (March 16, 1951). In Records of the Office of the Historian. Japanese Peace and Security Treaties, 1946-1952 [microfilm] (Lot File 78 D 173). Box no. 2, Folder no. 8, Reel no. 9. (Modern Japanese Political History Materials Room, Japanese National Diet Library). p. 6.

${ }^{70}$ Note that the United States handed this draft to Japan on March 27. See, Provisional Draft of a Japanese Peace Treaty. In DJFP: Records (Vol. 2). pp. 519-520.

${ }^{71}$ Paragraph 12 provided that, "The power ... may not be exercised except jointly by Japan and the Government or Governments ..." Provisional United States Draft of a Japanese Peace Treaty. In [1951] FRUS (Vol. 6). p. 947; Treaty Draft March 22, 1951. In Records of the Office of Northeast Asian Affairs, Relating to the Treaty of Peace with Japan [microfilm] - Subject File, 1945-51 (Lot File 56 D 527). Box no. 6, Folder no. 5, Reel no. 6. (Modern Japanese Political History Materials Room, Japanese National Diet Library). p. 4.

72 The United Kingdom analyzed this provisional draft obligating Japan to ensure that convicted war criminals should serve the prison terms to which they were sentenced by war crimes trials. See, The Substance of the Treaty. Reprinted in C.P. (51) 104 (the United Kingdom National Archives). p. 45.

${ }^{73}$ The British provisional draft neither considered the aide-mémoire of March 13 nor the provisional draft of March 23 of the United States. See, Mr. Morrison to Sir O. Franks (Washington) (FJ 1022/222). Reprinted in C.P. (51) 104 (the United Kingdom National Archives). p. 6.

${ }^{74}$ The memorandum of Herbert S. Morrison, the Foreign Secretary of the United Kingdom, stated that his government should accept the suggestion of the United States' draft of the Japanese peace treaty that the power to grant amnesty should be exercised jointly by the governments of the Allied Powers concerned and the Japanese government. See, Memorandum by the Secretary of State for Foreign Affairs (C.P. (51) 104, the United Kingdom National Archives). p. 2.

${ }^{75}$ See, FO371/92532 (the United Kingdom National Archives). pp. 67-123.

${ }^{76}$ Article 21 provided that, "Japan undertakes to accept the judgments and carry out the orders ... respecting convictions and sentences imposed upon Japanese nationals." See, Provisional Draft of Japanese Peace Treaty (United Kingdom). Reprinted in C.P. (51) 104 (the United Kingdom National Archives). p. 16.

77 Article 21 provided that, "The power to grant clemency, reduction of sentences, and parole ... shall be exercised jointly by the Government of Japan and the Government or Governments which constituted the Courts ..." See, ibid.

The United Kingdom assumed the position of contradicting the terminology "pardon" on the grounds that "in England it could only mean that a war criminal would not only be released but that his conviction would be set aside," and that "it would be most objectionable to 


\subsection{Japan's Reaction toward the United Kingdom's Methodology}

The United States, which had received the draft from the United Kingdom, unofficially notified Japan of the draft; the United States disclosed Japan's views of the United Kingdom's methodology to modulate its own methodology for retribution. In response to the unofficial announcement, Japan communicated to the United States that it had no objection to the draft of the United Kingdom, as the British methodology's significance was identical to that of the United States. By its confidential receipt of the United Kingdom's draft through the United States on April 17, 1951, Japan noted its remarks on Article 21, specifically that the methodology of the United Kingdom, which was more rigid than that of the United States in the sense that the former comprised the execution of sentences, the obligation to jointly exercise the power to grant amnesty, and the omission of "pardon," had the same meaning as the methodology of the United States in the March 23 American draft. ${ }^{78}$ During the April 21 talks with the United States regarding the British draft, Japan consented to the provision on war criminals because the implication of this clause was identified as that in the draft of the United States. ${ }^{79}$

\section{Modulation and Determination of Methodology for Retribution}

\subsection{Concession by the United States}

In view of Japan's undisputed attitude toward the severe methodology of the United Kingdom, the United States, in the process of drafting the peace treaty jointly with the United Kingdom, reached a compromise with the United Kingdom by reinforcing the modification of reconciliation more than the March 23, 1951 draft; ${ }^{80}$ however, the United Kingdom hinted that it was dissatisfied with the extent of this intensification. The May 3 , 1951 jointly-drafted peace treaty did not stipulate Japan's acceptance and administration of sentences, solely because of the draft by the United States ${ }^{81}$ but it changed the mode of restraint from the one that set a limit to the manner of using the power to grant amnesty to the one that limited the contents of and power to grant amnesty itself via, (1) conditioning "pardon" into a permissible grant only when new evidence is discovered, and (2) divesting Japan of the direct right to exercise the power to grant amnesty and vesting it only with the indirect capability of making recommendations to the Allied Powers for exercising their authority. ${ }^{82}$ Yet, the United

provide in the Peace Treaty that any properly convicted war criminal could in any circumstances have his conviction reversed except by due process of law." See, The Substance of the Treaty, supra note 72, p. 45.

${ }^{78}$ Eikoku no tainichi heiwa jōyaku an [British provisional draft of the Treaty of Peace with Japan]. In DJFP: Records (Vol. 2). p. 618 (in Japanese).

In inner noticing, Robert A. Fearey, a member of the Office of Northeast Asian Affairs of the United States, stated that he conceived that to forward the negotiation between the United States and the United Kingdom amicably, the United States intended to adopt the clauses of the British draft, which had clauses similar to the American draft and to which the Japanese government had no intention of raising objection. Thus, Japan's description of Article 21 of the British draft is considered to suggest that Japan had no objection to this article at this juncture. See, Ministry of Foreign Affairs of Japan, supra note 51, p. 441 (in Japanese).

${ }^{79}$ Eikokuan ni taishi kōtō chinjyutsu shitaru waga kenkai wo osameta 4 gatsu 21 nichi no Nishimura jōyakukyokuchō Fearey kaidan kiroku [Record of conversations between Nishimura, Director of the Bureau of Treaties, and Fearey on April 21, which documented Japan's observations, stated verbally, of the British draft]. In DJFP: Records (Vol. 2). p. 631 (in Japanese).

Note that Japan protested mainly against Article 9 (undesirable political organizations), Article 10 (protection of Japanese who collaborated with Allied Powers), Article 14 (Congo Basin Treaties), Article 23 (provisions on bullions, precious stones, etc.), Article 28 (Japanese property in neutral countries and former enemy countries), Article 31 (pre-war claims), Article 34 (fisheries), and Article 40 (enforcement) of the British draft; therefore, Japan stated that the American draft was, by far, more realistic and preferable overall. See, Observations on the British Draft Peace Treaty for Japan. In DJFP: Records (Vol. 2). p. 625.

${ }^{80}$ On the other hand, the United Kingdom appeased the United States by accepting views of the United States on omitting clauses as to war guilt, stocks of Japanese gold, and other issues. See, Memorandum of Conversation, by the Second Secretary of the Embassy in the United Kingdom (Marvin). In [1951] FRUS (Vol. 6). p. 937; C.P. (51) 104 (the United Kingdom National Archives). p. 2; The Substance of the Treaty, supra note 72 , pp. 43-44, 46.

${ }^{81}$ There were no lines indicating the United Kingdom's contribution regarding clauses in the article for war criminals. See, Joint United States-United Kingdom Draft Peace Treaty. In [1951] FRUS (Vol. 6). pp. 1028-1029.

${ }^{82}$ Article 12 provided that, "The power to grant clemency, reduce sentences, parole and pardon (the last only when newly discovered evidence so warrants) with respect to the war crimes sentences imposed ... may not be exercised except on the decision of the Government or Governments which imposed the sentence in each instance, and on the recommendation of Japan..." See, Draft Japanese Peace Treaty. In Records of the Office of the Historian. Japanese Peace and Security Treaties, 1946-1952 [microfilm] (Lot File 78 D 173). Box no. 2, Folder no. 2, Reel no. 9. (Modern Japanese Political History Materials Room, Japanese National Diet Library). pp. 6-7. 
Kingdom enunciated the suspension of this article, on account of the first sentence of Article 21 of the British draft of April 7, and the adoption of the term "pardon." 83

Thereupon, the United States, determined to make an additional concession to the United Kingdom, ${ }^{84}$ prepared a revised joint draft that intensified the restriction on reconciliation even further than the May 3 joint draft. First, the June 14 revised joint draft, which was prepared because of the talks in London between Dulles and Morrison, ${ }^{85}$ provided, in the first sentence of Article 11, a novel stipulation specifying Japan's acceptance of the judgments and execution of sentences in accordance with the April 7 British draft, ${ }^{86}$ strongly expressing the intent of securing retribution. Second, the second sentence of the revised jointly drafted Article 11 omitted "pardon" from the May 3 joint draft, ${ }^{87}$ strengthening the restraint on the components of the power to grant amnesty.

The United States presented Japan with the rigorous methodology for retribution settled with the United Kingdom. However, Japan had no objection against this methodology. On June 28, Japan received Article 11 of the June 14 revised joint draft from Allison, Deputy to Dulles of the United States. ${ }^{88}$ After considering Article 11, Japan privately commented that the amendments would not be opposed, recognizing the modified sentences providing for its acceptance of convictions and restricting its capacity to grant amnesty by providing it with only the right to recommend. ${ }^{89}$

\subsection{Determination of Article 11 of the Treaty of Peace with Japan}

The United States and the United Kingdom reached an agreement on the extent of restriction on reconciliation, which was provided in the June 14, 1951 revised joint draft. Hence, Article 11 of the Treaty of Peace with Japan, setting the methodology for retribution by restraining reconciliation, was complete. The July 3 draft of the

${ }^{83}$ The note pertaining to Article 12 stated that, "U.K. reserves the first sentence of Article 21 of U.K. draft and on the use of the word "pardon." See, ibid., p. 7. See also, the memorandum of May 23 by Herbert S. Morrison, Foreign Secretary of the United Kingdom, summarizing the talks in Washington between the United Kingdom and the United States from April 25 to May 4, where the joint draft of May 3 was prepared. Memorandum by the Secretary of State for Foreign Affairs (C.P. (51) 137, the United Kingdom National Archives). p. 1. Note that Foreign Relations of the United States has not recorded the concrete contents of the talks in Washington. See, Editorial Note. In [1951] FRUS (Vol. 6). pp. 1021-1022.

${ }^{84}$ On the other hand, the United Kingdom agreed not to force its proposal for the distribution of Japanese gold as reparation. See, Editorial Note. In [1951] FRUS (Vol. 6). p. 1118.

${ }^{85}$ The talks between the United States and the United Kingdom resulted in full agreement between them on the draft treaty and on all other major related problems. See, 1951 nen 6 gatsu 14 nichi no bei ei rondon kaidan ni kansuru bei ei kyōdō seimei [Joint communiqué with regard to the talks in London between the United States and the United Kingdom on June 14, 1951]. In DJFP: Records (Vol. 3). pp. 344-345.

${ }^{86}$ Article 11 provided that, "Japan accepts the judgments of the International Military Tribunal for the Far East and of other Allied War Crimes Courts both within and outside Japan, and will carry out the sentences imposed thereby upon Japanese nationals imprisoned in Japan." See, Revised United States-United Kingdom Draft of a Japanese Peace Treaty. In [1951] FRUS (Vol. 6). p. 1123; Draft Japanese Peace Treaty. In Records of the Office of Northeast Asian Affairs, Relating to the Treaty of Peace with Japan [microfilm] - Subject File, 1945-51 (Lot File 56 D 527). Box no. 6, Folder no. 7, Reel no. 6. (Modern Japanese Political History Materials Room, Japanese National Diet Library). p. 6.

${ }^{87}$ Article 11 provided that, "The power to grant clemency, reduce sentences and parole ... may not be exercised except on the decision of the Government or Governments ... and on the recommendation of Japan." See, Revised United States-United Kingdom Draft of a Japanese Peace Treaty, supra note 86, p. 1123; Draft Japanese Peace Treaty, supra note 86, pp. 6-7.

${ }^{88} 1951$ nen 6 gatsu 28 nichi Allison kōshi yori juryō shita heiwa jōyaku shin anbun [New draft of the peace treaty received from Ambassador Allison on June 28, 1951]. In DJFP: Records (Vol. 3). pp. 362-363.

${ }^{89}$ See, Ministry of Foreign Affairs of Japan. (Ed.). (2002). DJFP: Records (Vol. 3). Tokyo: Ministry of Foreign Affairs of Japan. p. 88 (in Japanese); 1951 nen 6 gatsu Allison kōshi kaidan kara 1951 nen 7 gatsu 13 nichi heiwa jōyaku an kōhyō ni itaru made no keika chōsho [Investigation as to the course from the talks with Ambassador Allison on June, 1951, to the publication of the draft of the Treaty of Peace with Japan on July 13, 1951]. In DJFP: Records (Vol. 3). p. 643 (in Japanese).

At the June 25 talks between Allison and Sadao Iguchi, Japanese Vice Minister of Foreign Affairs, where the revised June 14 joint draft including Article 11 was reported, Kumao Nishimura, Director of the Bureau of Treaties of the Ministry of Foreign Affairs of Japan, unofficially remarked that it was inevitable that the talks in London resulted in laying a heavier burden on Japan, but he was not rejoiced by this. See, Ministry of Foreign Affairs of Japan, supra note 89, p. 59 (in Japanese). 
Japanese peace treaty, ${ }^{90}$ which included the same provision as Article 11 of the June 14 draft, was sent to Japan on July $7^{91}$ and jointly published by the United States and the United Kingdom on July $12 .^{92}$ Next, the July 20 draft, ${ }^{93}$ including one clause from Article 11 of the July 3 draft, was delivered to the states that were to be invited to the peace conference in San Francisco. The final draft of the Treaty of Peace with Japan, ${ }^{94}$ which provided roughly the same article as Article 11 from the July 20 draft, ${ }^{95}$ was handed to Japan on August 15 and publicized on August $16 .^{96}$ Finally, the Treaty of Peace with Japan, Article $11^{97}$ of which was identified as that of the final draft, was adopted on September 8.

\section{Conclusion}

Based on the previous diachronic analyses of diplomatic negotiations while drafting the provisions relating to war criminals under the Treaty of Peace with Japan, the author concludes the following: Article 11 of the Treaty of Peace with Japan can be construed on its face as tweaking retribution for reconciliation, for according to this provision, Japan will execute sentences of war crimes trials, but at the same time, may make recommendations to the Allied Powers in exercising their power to grant amnesty. In reality, however, this provision crystallizes the methodology of strongly restraining reconciliation to secure retribution as the principle to the extent of restriction on reconciliation.

The foregoing considerations concluded from the earlier chapters can be corroborated by a range of theoretical rationales, which include the following: (1) Japan's study of and response to the July 12, 1951 draft peace treaty, which had essentially the same provision as Article 11 of the Treaty of Peace with Japan, suggested that the article regarding war criminals could be interpreted as an exception to the theory that all convictions became hereafter invalid unless the contrary was explicitly stipulated; in other words, all convicted war criminals were granted amnesty in peace treaties. ${ }^{98}$ Accordingly, reading the context of the restraint to amnesty (reconciliation) into Japan's study should be possible; (2) At the peace conference in San Francisco, the delegates of Mexico and

${ }^{90}$ Treaty of Peace with Japan. In Records of the Office of the Historian. Japanese Peace and Security Treaties, 1946-1952 [microfilm] (Lot File 78 D 173). Box no. 2, Folder no. 8, Reel no. 9. (Modern Japanese Political History Materials Room, Japanese National Diet Library). pp. 6-7.

${ }^{91}$ Draft Japanese Peace Treaty. In DJFP: Records (Vol. 3). p. 581; Memorandum. In DJFP: Records (Vol. 3). pp. 576-577.

92 It was published on July 13 (Japanese Standard Time). See, Ministry of Foreign Affairs of Japan, supra note 89, p. 81 (in Japanese).

${ }^{93}$ Draft Treaty of Peace with Japan. In Records of the Office of Northeast Asian Affairs, Relating to the Treaty of Peace with Japan [microfilm] - Subject File, 1945-51 (Lot File 56 D 527). Box no. 6, Folder no. 8, Reel no. 6. (Modern Japanese Political History Materials Room, Japanese National Diet Library). p. 5.

94 Treaty of Peace with Japan. In DJFP: Records (Vol. 3). p. 762.

95 The Japanese government analyzed the modifications of Article 11 from the July 20 draft as merely the addition of the preposition "to," which had no effect on the Japanese translation. See, Ministry of Foreign Affairs of Japan, supra note 89, p. 212 (in Japanese).

${ }^{96}$ See, ibid., p. 211 (in Japanese).

${ }^{97}$ Article 11 of the Treaty of Peace with Japan provided that, "Japan accepts the judgments of the International Military Tribunal for the Far East and of other Allied War Crimes Courts both within and outside Japan, and will carry out the sentences imposed thereby upon Japanese nationals imprisoned in Japan. The power to grant clemency, to reduce sentences and to parole with respect to such prisoners may not be exercised except on the decision of the Government or Governments which imposed the sentence in each instance, and on the recommendation of Japan. In the case of persons sentenced by the International Military Tribunal for the Far East, such power may not be exercised except on the decision of a majority of the Governments represented on the Tribunal, and on the recommendation of Japan." See, Treaty of Peace with Japan. In Records of the Office of Northeast Asian Affairs, Relating to the Treaty of Peace with Japan [microfilm] Subject File, 1945-51 (Lot File 56 D 527). Box no. 4, Folder no. 3, Reel no. 4. (Modern Japanese Political History Materials Room, Japanese National Diet Library); Treaty of Peace with Japan. In DJFP: Records (Vol. 5). pp. 616-617.

${ }^{98}$ Explanatory Study of Draft Japanese Peace Treaty, supra note 31, p. 24; Nihon koku to no heiwa jōyaku sōan no kaisetsu [Explanatory Study of Draft Japanese Peace Treaty], supra note 31, p. 683 (in Japanese).

This official interpretation was endorsed in the Diet of Japan. On this point, see, the statements of Kumao Nishimura, Director of the Bureau of Treaties of the Ministry of Foreign Affairs, at the October 17, 1951, meeting of the special committee of the House of Representatives for the Treaty of Peace with Japan and the Security Treaty between Japan and the United States and at the October 26, 1951, meeting of the special committee of the House of Councilors for the Treaty of Peace with Japan and the Security Treaty between Japan and the United States. 
El Salvador asserted that the restriction of Japan's power to grant amnesty should be loosened, ${ }^{99}$ implying that they deemed the legal effect of Article 11 of the final draft as restraining amnesty (reconciliation); (3) All convicted war criminals relating to the Republic of China were discharged as a result of the exclusion of the application of Article 11 of the Treaty of Peace with Japan by Paragraph 1(c) of the Protocol of the Treaty of Peace between Japan and the Republic of China. From this fact, it is reasonable to suppose that Article 11 of the Treaty of Peace with Japan possessed the legal effect of restraining amnesty (reconciliation), so that amnesty in peace treaties was invoked since the restriction of the power to grant amnesty was discarded in the Treaty of Peace between Japan and the Republic of China; ${ }^{100}$ (4) Recognizing the legal effect of Article 11 of the Treaty of Peace with Japan as limiting reconciliation is consistent with the course of tempering "soft peace," which is adopted as the liberal concept connoting lenient legal effects in the Treaty of Peace with Japan, with sternness during the process of drafting this treaty as a whole. ${ }^{101}$

The present article attempts to answer the question of how to balance the antagonism between retribution and reconciliation, or between punishment and amnesty, which can be raised with regard to post bellum norms. An answer to this question, based on the case study of the Treaty of Peace with Japan, provides the possibility of adopting the methodology of restraining reconciliation to secure retribution to the extent of restriction on reconciliation. This answer results in the conclusion that restraining reconciliation for retribution as well as relaxing retribution for reconciliation is acceptable for implementing post bellum norms.

\section{Acknowledgements}

The author is indebted to Professor Masahito Omori, Keio University, for his helpful suggestions and comments. However, responsibility for the text (including errors) rests solely upon the author.

\section{Copyrights}

Copyright for this article is retained by the author(s), with first publication rights granted to the journal.

This is an open-access article distributed under the terms and conditions of the Creative Commons Attribution license (http://creativecommons.org/licenses/by/3.0/).

\footnotetext{
99 Rafael de la Colina (Ambassador of Mexico to the United States) stated that, "We would have desired a different wording in article 11 in order to give greater freedom to the Japanese nation to grant pardon to those of the political prisoners who were most deserving." Héctor David Castro (Ambassador of El Salvador to the United States) stated that, "Article 11 of the treaty in question very radically limits the powers of Japan to grant clemency or conditional liberty and commute sentences pronounced for punishment of the guilty deeds classed as war crimes. The Salvadoran Delegation would have preferred that the Treaty of Peace recognize greater latitude for the Japanese Government to take action on the said cases, for this would have emphasized still more the humanitarian character of this treaty and would at the same time have given to the people and the Government of Japan a new demonstration of the confidence which we have in the spirit of justice which now inspires their acts." See, Records of Proceedings: Conference for the Conclusion and Signature of the Treaty of Peace with Japan. (1951). Washington, D.C.: Department of State. pp. 98, 140; Ministry of Foreign Affairs. (1951). Provisional Verbatim Minutes of the Conference for the Conclusion and Signature of the Treaty of Peace with Japan. Tokyo: Ministry of Foreign Affairs. pp. $100,145$.

${ }^{100}$ It is likely that Japan and the Republic of China had the intent to grant amnesty to the convicted, relating to the Republic of China. In this regard, Paragraph 3 of the draft agreement between Japan and the Republic of China provided that, "The National Government of the Republic of China agrees that the Japanese nationals imprisoned in Japan on the judgements of the Chinese War Crimes Courts be freed on the coming into force of the present Agreement." See, Draft Agreement concerning the Establishment of Normal Relations between the Government of Japan and the National Government of the Republic of China (An Outline). In DJFP: Records (Vol. 1). p. 494.

${ }^{101}$ See, Minai, K. (2014). Emergence of Studies into Contemporary International Law with Regard to Rules and Principles for Peace-making: From the Perspective of Diachronic Analyses of Diplomatic Negotiations after the World Wars. International Law Research, 3(1), 86-122. pp. 104-121.
} 